УДК 336.714:332.83

\title{
ІНСТИТУТИ СПІЛЬНОГО ІНВЕСТУВАННЯ ЯК ФОРМА ІНВЕСТУВАННЯ В БУДІВНИЦТВО ЖИТЛА
}

\author{
Ю. Гладьо \\ Львівський національний університет імені Івана Франка, \\ вул. Університетська, 1, Львів, Україна, 79000, \\ e-mail: yuliya.glado@gmail.com
}

3'ясовано поняття та форми інвестування в будівництво житла, до яких чинне законодавство відносить фонди фрінансування будівництва, фонди операцій з нерухомістю, інститути спільного інвестування та емісію цільових облігацій підприємств, виконання зобов'язань за якими відбувається шляхом передачі об'єкта (частини об'єкта) житлового будівництва. Виокремлено особливості інвестування в будівництво житла через інститути спільного інвестування - корпоративний та пайовий фонди. Запропоновано під інвестором, що фрінансує (інвестує в) будівництво через інститут спільного інвестування розуміти саме учасника відповідного інституту, який придбав цінні папери та в інтересах якого відбувається спільне інвестування інституційним інвестором. Наголошено на невідповідності окремих механізмів інвестування в будівництво, що використовуються на практиці, вимогам Закону України “Про інвестиційну діяльність”, у зв'язку з широким трактуванням поняття інвестування через інститути спільного інвестування.

Ключові слова: інвестування в будівництво житла, інститути спільного інвестування, форвардний контракт, інвестиційний договір, цільові облігації підприємств, виконання зобов'язань за якими відбувається шляхом передачі об'єкта (частини об'єкта) житлового будівництва.

DOI: http://dx.doi.org/10.30970/vla.2020.70.151

Інвестування в будівництво житла на сьогодні є однією з найбільш розвинених галузей суспільних відносин. При цьому законодавче регулювання цієї сфери не містить єдиних підходів до форм та механізмів інвестування. Відтак, кожен інвестор обирає найбільш прийнятний для себе спосіб. Інститути спільного інвестування досить широко використовують як колективну форму інвестування в будівництво, що призначена зменшити негативні ризики втрати інвестиції. Водночас, застосування інститутів спільного інвестування в будівництві подекуди не відповідає вимогам чинного законодавства.

Питання діяльності інститутів спільного інвестування висвітлено у працях О. Гнатів, О. Гарагонича, О. Кібенко, Д. Клапатого, О. Слободяна, І. Полянської, Т. Рима, О. Яворської. Окрім того, у цій статті поставлено завдання дослідити механізми інвестування в будівництво житла через інститути спільного інвестування, визначити ризики такого інвестування, а також запропонувати зміни до законодавства України з метою уніфікації підходів до інвестування у будівництво житла.

Поняття інвестування в будівництво житла. Відповідно до ч. 1 ст. 1 Закону України "Про інвестиційну діяльність", інвестиціями є всі види майнових та інтелектуальних цінностей, які вкладають в об'єкти підприємницької та інших видів діяльності, в результаті якої створюється прибуток (доход) та/або досягається соціальний та екологічний ефект [9]. Своєю чергою інвестування у будівництво житла має певну специфіку та особливості, зважаючи на характер та суб'єктний

(С) Гладьо Ю., 2020 
склад таких правовідносин. Зокрема, варто звернути увагу на алеаторність правочинів, які вчиняють на ринку нерухомості щодо інвестування будівництва, адже такі $\epsilon$ ризиковими як для інвестора, так і для забудовника. 3 цих підстав основне завдання полягає у забезпеченні інвесторам гарантій при вкладенні коштів у будівництво житла, з одного боку, а також зменшення податкового навантаження на забудовника чи окремих юридичних осіб, які залучають такі інвестиції, 3 другого. Власне тому чинне законодавство обмежує механізми залучення коштів фізичних та юридичних осіб для інвестування та фінансування житлового будівництва.

Керуючись ч. 3 ст. 4 Закону України “Про інвестиційну діяльність”, здійснення інвестицій та будівництваоб'єктів житлового будівництва у разі залучення недержавних коштів від фізичних та юридичних осіб може відбуватися винятково через фонди фінансування будівництва (ФФБ), фонди операцій з нерухомістю $(Ф \mathrm{OH})$, інститути спільного інвестування (ICI), а також шляхом емісії цільових облігацій підприємств, виконання зобов'язань за якими відбувається шляхом передачі об'єкта (частини об'єкта) житлового будівництва.

Застосування будь-яких інших механізмів інвестування в житло забороняється, крім випадків, якщо цей спосіб інвестування прямо не встановлений законом. Відтак, ICI є одним зі способів інвестування в будівництво та фінансування будівництва житла.

Особливості інвестування через ICI. Інститути спільного інвестування - це колективна форма залучення інвестицій. ICI належать до інституційних інвесторів поряд 3 інвестиційними фондами, взаємними фондами інвестиційних компаній, недержавними пенсійними фондами, фондами банківського управління, страховими компаніями та іншими фінансовими установами, які проводять операції з фінансовими активами в інтересах третіх осіб за власний рахунок чи за рахунок цих осіб, а також за рахунок залучених від інших осіб фінансових активів з метою отримання прибутку або збереження реальної вартості фінансових активів [11]. Водночас, у проекті Закону "Про внесення змін до деяких законодавчих актів України щодо спрощення залучення інвестицій та запровадження нових фінансових інструментів", який прийнято за основу Верховною Радою України 19.12.2019 року, інституційні інвестори - це інвестори у фінансові інструменти, до яких відносять цінні папери, деривативні (похідні) фінансові інструменти, інструменти грошового ринку [7].

Правове регулювання діяльності інститутів спільного інвестування як інституційних інвесторів забезпечує Закон України "Про інститути спільного інвестування” [10], де зазначено, що інститут спільного інвестування - корпоративний або пайовий фонд. Корпоративний фонд (КФ) є юридичною особою, що створюється у формі акціонерного товариства та здійснює діяльність винятково зі спільного інвестування. Що ж стосується пайового фонду (ПФ), то останній не є юридичною особою, а фактично становить сукупність активів, що належать учасникам такого фонду на праві спільної часткової власності, та які перебувають в управлінні компанії з управління активами та обліковуються нею окремо від результатів іiі господарської діяльності. Сам фонд створює компанія 3 управління активами. Управління діяльністю як корпоративного, так і пайового фонду забезпечує компанія 3 управління активами (КУА). При цьому спектр прав щодо управління фондом в учасників корпоративного фонду ширший, ніж в учасників пайового фонду. На відміну від перших, останні не вправі змінити компанію з управління активами у випадку неналежного виконання нею своїх обов'язків, унаслідок чого можна констатувати фактичну безправність інвесторів пайового фонду. 
Ю. Гладьо

ISSN 0136-8168. Вісник Львівського університету. Серія юридична. 2020. Випуск 70

3 метою 3'ясування правових механізмів інвестування у будівництво через інститути спільного інвестування потрібно спершу вирішити, хто ж виступатиме інвестором у цих правовідносинах. Як вбачається із системного аналізу згаданого вже положення ч. 3 ст. 4 Закону України "Про інвестиційну діяльність", інвестором $\epsilon$ фізична чи юридична особа, що інвестує чи фінансує житлове будівництво за рахунок недержавних коштів через інститути спільного інвестування [9]. Водночас, із положень Закону України «Про інститути спільного інвестування» випливає, що інвесторами є учасники пайового чи корпоративного фонду. Частина перша статті четвертої цього закону встановлює, що учасник ICI - особа, яка $є$ власником цінних паперів інституту спільного інвестування. Учасниками корпоративного фонду є особи, які набули акції корпоративного фонду, а пайового фонду власники інвестиційних сертифікатів [10].

Очевидно, аналізуючи інвестування за допомогою інститутів спільного інвестування, потрібно виділяти два рівні правовідносин: 1) між фізичною чи юридичною особою, яка інвестує кошти у інститут спільного інвестування та власне самим інститутом спільного інвестування (КУА); 2) між інститутом спільного інвестування (інституційним інвестором) та третіми особами щодо набуття активів.

У першому виді правовідносин - особа набуває статусу «інвестора» 3 моменту набуття акцій корпоративного фонду чи інвестиційних сертифікатів пайового фонду. Своєю чергою акція корпоративного інвестиційного фонду посвідчуватиме майнові права учасника фонду, в тім числі право на отримання дивідендів (для закритого корпоративного інвестиційного фонду), частини майна корпоративного інвестиційного фонду у разі його ліквідації, право на управління корпоративним фондом, а також немайнові права, передбачені законодавством про інститути спільного інвестування [11]. При цьому, інвестори пайового фонду набувають інвестиційні сертифікати, емітентом яких $є$ компанія з управління активами пайового інвестиційного фонду та які, на відміну від акцій корпоративного фонду, засвідчують не право на управління фондом, а право власності учасника пайового фонду на частку в пайовому фонді та право на отримання дивідендів (для закритого пайового фонду).

Другий вид правовідносин фактично спрямований на реінвестування інституційним інвестором коштів у певні активи, в тім числі і в об'єкти житлового будівництва. Тобто на цьому етапі реалізується діяльність зі спільного інвестування - діяльність, яка провадиться в інтересах учасників інституту спільного інвестування та за рахунок інституту спільного інвестування шляхом вкладення коштів спільного інвестування в активи інституту спільного інвестування.

Отже, можна підсумувати, що інвестором ICI виступає винятково особа, яка вклала кошти в ICI та набула акції КФ чи інвестиційні сертифікати ПФ, що посвідчують певний правовий зв'язок між інституційним інвестором та цією особою. Спільне інвестування - це діяльність ICI в інтересах його учасників, відтак, така діяльність не може відбуватися на користь третіх осіб.

Механізми інвестування в будівництво житла через ICI. На практиці механізми інвестування в будівництво житла через інститути спільного інвестування дещо відрізняються, а саме інвестування фізичних чи юридичних осіб не відповідає правовій природі участі в корпоративному чи пайовому фондах. На сьогодні поширеними є так звані «квазіінвестування через ICI» чи інвестування 3 частковим залученням інститутів спільного інвестування. Як правило, воно характеризується своєрідним розподілом коштів, які надходять від фізичних чи юридичних осіб, між забудовником та інститутом спільного інвестування шляхом 
укладення двох чи більше правочинів, при цьому жоден 3 таких правочинів не матиме кінцевим результатом участі інвестора в ICI.

Серед механізмів залучення коштів у будівництво житла можна виділити такі:

1. Механізм «попередніх договорів». Цей спосіб складається 3 декількох етапів: 1) укладення інвестиційного договору між КУА (в інтересах ICI) та забудовником про фінансування будівництва, де кожна зі сторін визначає свою участь у фінансуванні будівництва та розподіляє частки; 2) укладення попереднього договору купівлі-продажу житла між КУА та фізичною чи юридичною особою, яка має намір придбати житло; 3) укладення договору купівлі-продажу нерухомого майна між КУА та покупцем - «інвестором».

За своєю суттю «інвестування» такого типу ніяк не відрізняється від стандартного укладення попередніх договорів купівлі-продажу. Однак несе значні ризики для покупця.

Відповідно до ч. 1 ст. 635 ЦК України, попереднім є договір, сторони якого зобов'язуються протягом певного строку (у певний термін) укласти договір у майбутньому (основний договір) на умовах, встановлених попереднім договором.

На етапі укладення таких попередніх договорів здебільшого будинок, в якому придбано житло, не введений в експлуатацію, а, відтак, продавець не набув права власності на майно та невідомі параметри житла. Попередній договір купівліпродажу повинен містити істотні умови договору купівлі-продажу, в тім числі і щодо предмета такого договору, або ж містити порядок погодження таких умов. На забезпечення виконання договору «інвестор» вносить гарантійний платіж, який підлягає зарахуванню як оплату за договором купівлі-продажу. Однак для покупця немає жодних механізмів впливу на забудовника чи ICI щодо вчасної здачі будинку в експлуатацію та оформлення права власності на житло.

Очевидно, така схема має право на існування, однак, вона не надає жодних гарантій «інвестору», які встановлені Законом України «Про інститути спільного інвестування» та й загалом цей закон не застосовуватиметься до описаних правовідносин. Правовідносини між покупцем та продавцем (КУА) в цьому випадку не можна означити як діяльність зі спільного інвестування, оскільки покупець не $є$ учасником ICI та не набув жодних цінних паперів ICI.

2. Набуття житла шляхом придбання фінансових інструментів. Цей алгоритм належить до змішаного типу інвестування та складається 3 декількох етапів: 1) укладення форвардного контракту між КУА в інтересах пайового фонду та особою, яка володіє майновими правами на об'єкт будівництва та є замовником будівництва (де замовник будівництва $є$ продавцем, а КУА покупцем базового активу); 2) укладення договору купівлі-продажу фінансового інструменту (деривативу) між брокером (представником «інвестора») та КУА; 3) укладення договору купівліпродажу майнових прав між замовником будівництва та безпосередньо особою, що набула фінансовий інструмент (дериватив).

Дериватив - стандартний документ, що засвідчує право та/або зобов'язання придбати або продати базовий актив на визначених ним умовах у майбутньому. До деривативів належать: форвардний контракт; ф’ючерсний контракт; опціон [2]. Своєю чергою під форвардним контрактом розуміють двосторонню угоду за стандартною (типовою) формою, яка засвідчує зобов'язання особи придбати (продати) базовий актив у визначений час та на визначених умовах у майбутньому, з фіксацією цін такого продажу під час укладення форвардного контракту.

На першому етапі КУА укладає зі забудовником форвардний контракт, про набуття базового активу в майбутньому. Під базовим активом розуміють майнові 
Ю. Гладьо

ISSN 0136-8168. Вісник Львівського університету. Серія юридична. 2020. Випуск 70

права на окрему квартиру, що буде зареєстрована як об'єкт нерухомого майна після завершення будівництва багатоквартирного житлового будинку. Тобто відчужується майнове право на купівлю майнових прав. Форвардний контракт підлягає реєстрації на товарній біржі, що фактично унеможливлює перепродаж майнових прав на той самий об'єкт.

Зокрема, А.С. Савченко зазначає, що форвардний контракт у будівництві житла - це договір, який повинен бути виконаний на умовах, прописаних у договорі в момент укладання угоди. У договорі мають бути чітко зафіксовані певні умови: зокрема, курс валюти, сума, яку покупець повинен сплатити забудовнику, термін виконання договору (завершення будівництва, введення в експлуатацію), технічна характеристика нерухомості (квартири) [13].

На другому етапі КУА та брокер (повірений покупця) укладає договір купівліпродажу фінансового інструменту. Таким фінансовим інструментом є форвардний контракт. Фактично внаслідок купівлі фінансового інструменту, покупець («інвестор») одержує право в майбутньому укласти договір купівлі-продажу майнових прав, які $\epsilon$ предметом форвардного контракту.

На третьому етапі замовник будівництва та покупець фінансового інструменту укладають договір купівлі-продажу майнових прав на набуття в майбутньому права власності на житло.

Як бачимо, цей алгоритм, як і попередній, не передбачає участі інвестора в ICI, a ICI фактично є тільки посередником між інвестором та замовником будівництва щодо набуття майнових прав. Очевидно, механізм продуманий з метою зменшення податкового навантаження. Водночас, як і в ситуації з попередніми договорами «інвестор» фактично є безправним та не має засобів впливу, ні на забудовника, ані на ICI щодо вчасної здачі будинку в експлуатацію або ж відшкодування коштів, вкладених у будівництво.

Проблема полягає в тому, що взяті сторонами зобов'язання як за договором купівлі-продажу фінансового інструменту, так i за договором купівлі-продажу майнових прав $є$ виконаними ще до набуття права власності на житло. Відтак, постає питання, як повернути кошти інвестору? За своєю суттю договір купівлі-продажу фінансового інструменту вважатиметься виконаним 3 моменту підписання акту приймання-передачі між брокером та КУА, адже КУА (ICI) передала фінансовий інструмент покупцю. Відтак, відсутні підстави для повернення покупцю коштів, що витрачені на його купівлю. Що ж стосується договору купівлі-продажу майнових прав між покупцем та замовником будівництва, то він теж вважатиметься виконаним 3 моменту підписання акту приймання-передачі майнових прав (що у переважній більшості випадків збігається 3 моментом укладення договору). Тобто зобов'язання за згаданими договорами вважатимуться виконаними як КУА, так і замовником будівництва (продавцем) ще до набуття права власності на житло покупцем. Отже, жоден із цих правочинів не дає гарантії щодо набуття права власності на житло потенційному покупцю та щодо повернення витрачених коштів.

Негативною для інвестора в цій ситуації також є судова практика у спорах про визнання права власності на нерухоме майно, адже у постанові Верховного Суду України у справі №6-318цс15 від 24 червня 2015 року [6] та постанові Верховного Суду України у справі № 6-1858цс15 від 18 листопада 2015 року [5] - зазначено, що визнання права власності в судовому порядку на новостворене майно за позовом, заявленим до будівельної компанії суперечить ст. ст. 15, 331 ЦК України, а в інвестора виникає право очікування на одержання у власність нерухомого 
майна. Цю ж позицію фактично висловила Велика Палата Верховного Суду у справі № 522/1029/18 [3].

Отже, інвестор набуває права очікування на одержання у власність житла, а договір купівлі-продажу майнових прав не свідчить про набуття ним права власності на нерухоме майно.

3. Інвестування ICI в цільові облігації підприємств, виконання зобов'язань за якими відбувається шляхом передачі об'єкта (частини об'єкта) житлового будівництва.

Якщо керуватися положеннями ч. 3 ст. 4 Закону України «Про інвестиційну діяльність», то інвестування через інститути спільного інвестування та шляхом емісії цільових облігацій підприємств є двома різними способами інвестування у будівництво житла. Натомість, на практиці вони поєднуються.

Цільові облігації відповідно до Закону України «Про цінні папери та фондовий ринок» - це облігації, виконання зобов'язань за якими відбувається шляхом передачі товарів та/або надання послуг, а також шляхом сплати коштів власнику таких облігацій.

Законом України «Про внесення змін до деяких законодавчих актів України щодо облігацій» від 02.06.2011 внесені зміни до Закону України «Про цінні папери та фондовий ринок», якими передбачено можливість випуску цільових облігацій підприємств, виконання зобов'язань за якими відбувається шляхом передачі об'єкта (частини об'єкта) житлового будівництва [6]. Порядок випуску і реєстрації облігацій регулює рішення НКЦПФР № 425 «Про затвердження Положення про порядок здійснення емісії облігацій підприємств та їх обігу» від 21.06.2018 року [8].

Позитивним моментом при інвестуванні в цільові облігації $\epsilon$ те, що законом чітко визначено заборону накладення емітентом таких облігацій будь-яких обтяжень на об'єкт житлового будівництва, земельну ділянку, яка призначена для спорудження об'єкта житлового будівництва, та на майнові права на них. Ця вимога захищає потенційних інвесторів від звернення стягнення третіх осіб на майно, яке підлягає переданню на погашення боргового зобов'язання за облігацією.

Інвестування шляхом придбання облігацій через ICI умовно можна поділити на такі етапи:

1) Створення ICI та випуск облігацій. На цьому етапі створюється ICI-пайовий венчурний фонд або венчурний корпоративний фонд. Його учасники купують акції КФ чи інвестиційні сертифікати ПФ, чим фактично наповнюють коштами для подальшого інвестування у цільові облігації. Доцільно наголосити на тому, що, відповідно до Закону України «Про інститути спільного інвестування», венчурні фонди є ризиковішими, проте мають ширші можливості щодо інвестування, ніж інші ICI.

Одночасно зі створенням венчурного фонду забудовник провадить емісію облігацій, що спрямована на залучення коштів у будівництво. Облігації існують у бездокументарній формі та зберігаються у відповідного ліцензованого зберігача.

2) Придбання ICI облігацій. Після випуску облігацій забудовник продає їх ICI за номінальною вартістю. Як правило такий продаж відбувається пакетом без чіткого визначення ознак приміщення, яке підлягає передачі внаслідок погашення облігацій. Відтак, у подальшому для ідентифікації квартири між інвестором та забудовником укладено окремий договір (бронювання чи участі в будівництві), де чітко зафіксовано ознаки житла.

3) Придбання облігацій «інвесторами». Таке придбання відбувається за ринковою вартістю (номінальна вартість + дохід) [1, с. 113]. 
4) Останнім етапом є погашення облігацій забудовником, унаслідок чого забудовник передає інвесторам житло, визначене у договорі бронювання.

Цей механізм так само, як перший та другий не передбачає участі інвестора в ICI, що фактично не поширює дію Закону України «Про інститути спільного інвестування» на ці правовідносини. Однак він $є$ цілком допустимим, оскільки в Законі України «Про інвестиційну діяльність» прямо дозволено інвестувати в житло через придбання цільових облігацій підприємств.

Найбільша проблема для інвесторів у цьому способі інвестування - це ідентифікація придбаного приміщення, оскільки облігації не містять індивідуальних ознак майна, яке повинно бути передане інвестору. Відтак, на практиці виникають ситуації. Коли на одну і ту ж квартиру оформлено декілька договорів бронювання квартири (аналогічні питання порушувалися у вже згаданій постанові Великої Палати Верховного Суду від 18 грудня 2019 року у справі № 522/1029/18) [3].

Проаналізувавши механізми, які застосовують при інвестуванні будівництва житла через ICI, доходимо до висновку, що жоден із наведених механізмів не передбачає участі інвестора (покупця житла) в ICI, що фактично, не відповідає вимогам Закону України «Про інститути спільного інвестування». За своєю природою, діяльність зі спільного інвестування передбачає обов'язкову участь інвестора у ICI, набуття цінних паперів ICI, унаслідок чого саме у такого інвестора виникає спектр прав, передбачений для учасника ICI. Водночас, досліджені у статті механізми інвестування у будівництво житла мають змішану природу зі застосуванням різних договірних конструкцій, що подекуди не відповідають вимогам ч. 3 ст. 4 Закону України «Про інвестиційну діяльність». Проблема полягає у тому, що у цьому законі використовується поняття «інвестор», натомість у законі «Про інститути спільного інвестування» йдеться про учасників та не подано визначення інвестору, що своєю чергою дозволяє інвестування через ICI не тільки учасникам, а й третім особам. Вочевидь, норми цих двох законів варто узгодити, чітко зазначивши, що інвесторами ICI $\epsilon$ його учасники, а діяльність зі спільного інвестування реалізується для задоволення інтересів учасників.

\section{Список використаних джерел}

1. Гарагонич $О$. В. Актуальні питання використання інститутів спільного інвестування в сфері господарювання // Юридичний науковий електронний журнал - електронне наукове видання. 2014. С. 109-115.

2. Положення про вимоги до стандартної (типової) форми деривативів: постанова Кабінету Міністрів України від 19 квітня 1999 р. № 632. URL: https://zakon.rada.gov.ua/laws/show/632-99-\%D0\%BF/print

3. Постанова Великої Палати Верховного Суду у справі № 522/1029/18 від 18 грудня 2019 року. Єдиний державний реєстр судових рішень. URL: http://www.reyestr.court.gov.ua/Review/87144996

4. Постанова Верховного Суду України у справі № 6-1858цс15 від 18 листопада 2015 року. Єдиний державний реєстр судових рішень. URL: http://www.reyestr.court.gov.ua/Review/53660469

5. Постанова Верховного Суду України у справі №6-318цс15 від 24 червня 2015 року. Єдиний державний реєстр судових рішень. URL: http://www.reyestr.court.gov.ua/Review/45910640

6. Про внесення змін до деяких законодавчих актів України щодо облігацій: Закон України від 2 червня 2011 року. URL: https://zakon.rada.gov.ua/laws/show/3461-17 
7. Про внесення змін до деяких законодавчих актів України щодо спрощення залучення інвестицій та запровадження нових фінансових інструментів: проект Закону № 2284 від 17.10.2019. URL: http://w1.c1.rada.gov.ua/pls/zweb2/webproc4_1?pf3511=67117

8. Про затвердження Положення про порядок здійснення емісії облігацій підприємств та ïх обігу: рішення НКЦПФР № 425 від 21.06.2018 року. URL: https://zakon.rada.gov.ua/laws/show/z0843-18

9. Про інвестиційну діяльність: Закон України від 18 вересня 1991 року. URL: https://zakon.rada.gov.ua/laws/show/1560-12

10. Про інститути спільного інвестування: Закон України від 5 липня 2012 року. URL: https://zakon.rada.gov.ua/laws/show/5080-17/print

11. Про цінні папери та фондовий ринок: Закон України від 23 лютого 2006 року. URL: zakon.rada.gov.ua/laws/show/3480-15/print

12. Савченко A. C. Передумови укладення форвардних контрактів у сфері інвестування будівництва житла // Публічне право. 2018. № 2. C. 221-226. URL: http://nbuv.gov.ua/UJRN/pp_2018_2_30.

\section{References}

1. Garagonych, O. V. (2014). Aktualni pytannia vykorystannia instytutiv spilnoho investuvannia $\mathrm{v}$ sferi gospodariuvannia. Yurydychnyy naukovyy elektronnyy zhurnal-elektronne naukove wydannia, 109-115.

2. Polozhennia pro vymohy do standartnoyi (typovoyi) formy deryvatyviv: postanova Kabinetu Ministriv Ukrayiny vid 19 kvitnya 1999 r. № 632. Retrieved from https://zakon.rada.gov.ua/laws/show/632-99-\%D0\%BF/print

3. Postanova Velykoyi Palaty Verkhovnoho Sudu u spravi № 522/1029/18 vid 18 hrudnya 2019 roku. Yedynyy derzhavnyy reyestr sudovykh rishen'. Retrieved from http://www.reyestr.court.gov.ua/Review/87144996

4. Postanova Verkhovnoho Sudu Ukrayiny u spravi № 6-1858tss15 vid 18 lystopada 2015 roku. Yedynyy derzhavnyy reyestr sudovykh rishen'. Retrieved from http://www.reyestr.court.gov.ua/Review/53660469

5. Postanova Verkhovnoho Sudu Ukrayiny u spravi №6-318tss15 vid 24 chervnya 2015 roku. Yedynyy derzhavnyy reyestr sudovykh rishen'. Retrieved from http://www.reyestr.court.gov.ua/Review/45910640

6. Pro vnesennya zmin do deyakykh zakonodavchykh aktiv Ukraïny shchodo oblihatsiy: Zakon Ukrayiny vid 2 chervnya 2011 roku. Retrieved from https://zakon.rada.gov.ua/laws/show/3461-17

7. Pro vnesennya zmin do deyakykh zakonodavchykh aktiv Ukrayiny shchodo sproshchennya zaluchennya investytsiy ta zaprovadzhennya novykh finansovykh instrumentiv: proekt Zakonu № 2284 vid 17.10.2019. Retrieved from http://w1.c1.rada.gov.ua/pls/zweb2/webproc4_1?pf3511=67117

8. Pro zatverdzhennya Polozhennya pro poryadok zdiysnennya emisiyi oblihatsiy pidpryyemstv ta yikh obihu: rishennya NKTSPFR № 425 vid 21.06.2018 roku. Retrieved from https://zakon.rada.gov.ua/laws/show/z0843-18

9. Pro investytsiynu diyal'nist': Zakon Ukrayiny vid 18 veresnya 1991 roku. Retrieved from https://zakon.rada.gov.ua/laws/show/1560-12

10. Pro instytuty spil'noho investuvannya: Zakon Ukrayiny vid 5 lypnya 2012 roku. Retrieved from https://zakon.rada.gov.ua/laws/show/5080-17/print

11. Pro tsinni papery ta fondovyy rynok: Zakon Ukrayiny vid 23 lyutoho 2006 roku. Retrieved from

12. Savchenko, A. S. (2018) Peredumovy ukladennia forvardnyh kontraktiv u sferi investuvannia budivnytstva zhytla. Publichne pravo, № 2, 221-226. 
JOINT INVESTMENT INSTITUTES AS HOUSING CONSTRUCTION INVESTMENT FORM

\section{Y. Glado}

Ivan Franko National University of Lviv,

1, Universytetska Str., Lviv, Ukraine, 79000, e-mail: yuliya.glado@gmail.com

According to Part 1,Article 1 of the Law of Ukraine "On Investment Activity" investments are all kinds of property and intellectual values invested in objects of business and other activities, which result in profit (income) and / or social and environmental effect achievements. In turn, investing in housing construction has certain peculiarities, considering the nature and subjective composition of such relationships. In particular, attention should be paid to the aleatority of transactions made in the real estate market for investing in construction, as such are risky for both the investor and the developer.

For these reasons, the primary objective is to provide investors with guarantees during the housing construction investments, on the one hand, and to reduce the tax burden on the developer or the individual entities attracting such investments, on the other. Actually, therefore, the current legislation restricts the mechanisms of attracting funds from individuals and legal entities for investing and financing housing construction.

The investment and financing of housing construction with the attraction of non-state funds from individuals and legal entities, under Part 3, Article 4 of the Law of Ukraine "On Investment Activity", can be carried out exclusively through construction financing funds (CFF), real estate operations funds (REOF), joint investment institutes (JII), as well as through the issuance of target corporate bonds, which provide the fulfillment of obligations by transferring the object (part of the object) of housing construction.

The Law of Ukraine "On Joint Investment Institutes" which denotes that joint investment institutes are corporate and share fund regulates joint investment institutes activity. A corporate fund is a legal entity created in the form of a joint stock company and operates exclusively for the purpose of joint investment. As for the share fund, the latter is not a legal entity, but in fact consists of assets that belong to the members of such a fund under common ownership. The management company manages the fund and accountes its assets separately from the results of its business activities. An asset management company creates the fund itself. Corporate and share funds activities are both managed by an asset management company (AMC).

Joint investment mechanisms in housing construction carried out through $\mathrm{Jll}$ are the following: "preliminary contracts" mechanism; financial instruments purchase for housing construction; JII investment in the target corporate bonds, which provide the fulfillment of obligations by transferring the object (part of the object) of housing construction. Analyzing the mechanisms used in housing investing carried out through $\mathrm{JII}$, we conclude that none of the above mechanisms provide the participation of the investor in the JII, that, in fact, does not meet the requirements of the Law of Ukraine "On Joint Investment Institutes". By its very nature, joint investment activities require the obligatory participation of an investor in JII, the acquisition of securities of $\mathrm{JII}$, which results in enjoying the rights provided for a $\mathrm{JII}$ participant.

Keywords: housing construction investment, joint investment institutes, forward contract, investment contract, target corporate bonds, which provide the fulfillment of obligations by transferring the object (part of the object) of housing construction. 